\title{
Life Stories of Syrian Refugees: A Qualitative Study
}

\author{
Philia Issari, Anna Christopoulou, Athina Galika \\ Department of Psychology, National and Kapodistrian University of Athens, Athens, Greece \\ Email: issariph@psych.uoa.gr
}

How to cite this paper: Issari, P., Christopoulou, A., \& Galika, A. (2021). Life Stories of Syrian Refugees: A Qualitative Study. Psychology, 12, 1542-1560. https://doi.org/10.4236/psych.2021.1210097

Received: August 14, 2021

Accepted: October 18, 2021

Published: October 21, 2021

Copyright (อ 2021 by author(s) and Scientific Research Publishing Inc. This work is licensed under the Creative Commons Attribution International License (CC BY 4.0).

http://creativecommons.org/licenses/by/4.0/

\begin{abstract}
The present qualitative study adopted a narrative approach and a social justice, strengths-based outlook in order to explore the life stories of Syrian refugees who lived in Greece waiting to relocate to another EU country. Narrative inquiry places the participant in the center of the research process as the "expert" providing an opportunity to be heard in ways that might otherwise be dismissed, ignored or silenced. We conducted biographical narrative interviews, with the help of interpreters in the context of an NGO. Six participants narrated their life stories in a moving and relatively direct way: the times before the war in Syria, the biographical rupture in their lives once the war broke, the much-enduring journey from Syria to Greece across the Aegean sea, what had sustained them so far, their hopes for the future.
\end{abstract}

\section{Keywords}

Life Stories, Narrative, Biographical, Syrian, Refugees, Social Justice, Resilience, Greece

\section{Introduction}

In recent years, the political and social destabilization of war afflicted areas in the Middle East has resulted in transnational mass movements of people who have fled conflict, poverty, violence, persecution, and human rights violations in order to seek refuge and asylum for themselves and their families in Europe. The refugee crisis is a major topic of discussion and concern at humanitarian, political, economic, social and institutional levels worldwide, and especially in countries of entry in the Mediterranean region, as is the case of Greece, Italy and Spain (Operational Data Portal, 2021; UNHCR, 2018a). Since 2014, more than one and a half million people have passed mainly through the Greek islands (UNHCR, 2015) and between January 2016 and April 2021, 89,000 people received protection in Greece-including a great number of refugees from Syria 
(Aboud, 2018; Operational Data Portal, 2021; UNHCR, 2018a). This overwhelming flow came in the middle of a most severe financial crisis for the country, when little state attention or funding could be provided for the accommodation, medical, mental health and psychosocial care of refugees, as well as support for related research (Anagnostopoulos, Giannakopoulos, \& Christodoulou, 2017; Kalantzakos, 2017).

\section{Literature Review and Theoretical Framework}

The international literature on refugees covers a broad scope of research areas including statistics and data about country of origin, movement trends (UNHCR, 2018a), the construct of "home", and liminal spaces of temporary dwellings (Arvanitis, Yelland, \& Kiprianos, 2019), asylum policies (Mayblin, 2014), supervision of practioners working with refugees (Kesisoglou \& Issari, 2019), mental health and psychological well-being (Hassan, Ventevogel, Jefee-Bahloul, BarkilOteo, \& Kirmayer, 2016), refugees' integration and identity (Mohamed \& Bustag, 2021), and so on. Moreover, many studies have focused upon the nature, aetiology and diagnosis of refugee trauma and its negative impact upon refugee welfare and quality of life (Garoff et al., 2021; Papadopoulos, 2002). The emphasis has been on the exposure to trauma which can have significant effects on both physical and psychological well-being, enhancing the risk for psychiatric symptoms such as PTSD, depression and the negative consequences upon physical health (Bogic, Njoku, \& Briebe, 2015). Papadopoulos (2002) emphasized that the usual conceptualisation of refugees is in terms of trauma theories and within a "pathology, symptom-based or deficit model", which articulates a medicalised "trauma discourse" vis-a-vis their mental health. A greater focus on resilience and positive factors of adaptation among refugee people is thus necessary both in theoretical conceptualizations, related research and practice (Mohamed \& Bastug, 2021; Hutchinson \& Dorsett, 2012).

Another common portrayal of refugees is that of helpless people or passive victims, given that they are often compelled to flee from their countries to survive, and or are victims of violence, war crimes and other atrocities. Images related to refugees come mainly from the media or aid agencies and organizations that tend to emphasize "images of helpless refugees desperately in need ... images of starving masses who depend on agents of compassion to keep them alive." (Harrell-Bond's, 1999, p. 147 as cited in Ghorashi, 2005). In this context victimized refugees are perceived as passive dependants who are not able to act individually or as weak people whose ability for agency and choice-even limited choice-is overlooked. This is even more common in the case of women (Freedman, 2018; Hunt, 2008). Along these lines, Malkki (1996: p. 386) wrote of "speechless emissaries" referring to systematic, even if unintended, silencing of persons who find themselves in the classificatory space of "refugee," and connected humanitarianism with de-historicization. Humanitarian discourse tends to associate victimization and helplessness with the "archetypal" refugee construct while striping people from the authority to narrate their own condition 
and circumstances as historical actors (Mcmahon, Crawley, \& Jones, 2016). "The refugee" is frequently constructed "as a figure who is thought to 'speak' to us in a particular way: wordlessly" and we presume that "the refugee's physical presence is 'telling' of his or her immediate history of violence" (Malkki, 1996: p. 390). In fact, visual representations of refugees (photographs and other visual practices) are far more common than people's narratives or specific histories. Moreover, there is a tendency to abstract and universalize, to depersonalize, and to portray refugee mobility as an anonymous corporeality or as a "sea" of humanity (Malkki, 1996) which precludes the possibility of a personal connection or relationship.

Taking into account the issues discussed above namely: a "pathologising" perspective, and a construction of the refugee as a historical, helpless, often silenced subject, the present qualitative study aimed to facilitate Syrian people who found temporary refuge in Greece to articulate their stories, life struggles, narratives of resilience, experiences in the host country, as well as their hopes for the future. To this end we adopted a biographical narrative approach along with a strengths based and social justice outlook. Social justice is understood to represent a global struggle for human rights, recognition and dignity, and emphasizes an ethic of care, political praxis, and a contextualizing and non-pathologizing stance in relation to human issues (Johnson \& Parry, 2015). A strengths based outlook, while acknowledging the vulnerability which is associated with refugee people, it also takes into account resilience, their capacity to withstand, cope successfully or even thrive in spite of severe adversities in their lives (Masten, 2014). Narrative inquiry puts the participant in the center of the research process as the "expert" providing an opportunity to be heard in ways that might otherwise be dismissed, redirected, ignored or silenced. It draws mainly from the ontological and epistemological perspectives of narrative knowing (Bruner, 2002) which views human beings as making sense of their experiences and communicating them to others in the form of contextualized stories (Issari \& Karayianni, 2013). A story can portray participants' understanding of their socio-cultural and political world within which personal experiences are formed, constructed, expressed and performed (Smith \& Sparkes, 2006). Moreover, it allows for an image of the person as an active responsible agent striving to achieve meaning, control and empowerment (McLeod, 1997: p. 106). Stories construct and give meaning to our experiences, allowing us to understand ourselves and our life, shape our identity, justify our decisions, make attributions for the behavior of the others. They also can compose an autobiographical life-course which describes the starting point, the present, and the future (Polkinghorne, 1988) which has the potential to support the sense of selfcontinuity (Camia \& Zafar, 2021).

\section{Method}

\subsection{Participants}

Study participants were six Syrian refugees ( 3 women and 3 men, 40 - 65 years old) who lived in Greece between eight months to one and a half year waiting to 
relocate to another EU country. The sample was purposive allowing for the identification and selection of participants that are knowledgeable about the subject of inquiry, available and willing to communicate their experiences (Patton, 2002). Narrative research is a form of case-centred inquiry; it interrogates cases of individuals (rather than population-based samples) and thus inference is of a different kind (Riessman, 2008). All participants were selected in cooperation with an NGO working with refugees in the Athens area.

\subsection{Data Collection and Procedure}

For the collection of the data, biographical narrative interviews were conducted by the authors of the article in the year 2018. The main goal of this form of interview, which is considered a well established narrative genre (Mishler, 1986), is to generate detailed narratives rather than brief answers (stimulus/response model), or general statements (Riessman, 2008; Tsiolis, 2006). After an initial stage of small talk and "warm up", a generative question was presented that invited extended narration and encouraged informants to relate their stories. Participants were not interrupted, and we used paralinguistic, and non-verbal cues to encourage their narrations. Only, when their accounts' came to an end, we asked, additionally, more specific questions (question phase of the narrative interview) (Issari \& Pourkos, 2015). Interviews took place at a site of an NGO, in the city of Athens. We conducted them in Greek with the help of two Arabic-speaking interpreters in the context of an empathic, embodied intersubjective relationship (researcher-interpreter-participant) (Ellingson, 2017), and a relational ethic framework (Gergen, 2015). Informed consent was safeguarded, and issues related to interviewing via interpreters (Bergen, 2018; Tribe \& Thompson, 2011) were taken into account. The interpreter has a very active role and contributes to the research material which is co-created by his/her personal style and experiences (Temple \& Young, 2004). In all of the interviews, the interpreters through their intercultural experience, were a significant point of reference and contact in terms of the communication of cultural issues. The "intercultural translators" are valid sources of knowledge regarding cultural and social issues specific to the participants, a significant asset in the research process as it helps protect the participants as well as the validity of the research (Berman \& Tyyskä, 2011). Both interpreters seemed to have developed trusting relationships with the participants. The audiorecorded interviews were transcribed verbatim into Greek and the names of the participants were changed to preserve anonymity.

\subsection{Data Analysis}

Narrative thematic analysis (Riessman, 2008) of individual stories which places primary attention on content was employed. We analyzed a single narrative interview at a time, preserving the particularity of each story and the sequential, temporal features which are characteristic of narrative, and then proceeded to identify common patterns and variations comparing the different participants' 
accounts. The analysis took into consideration time, place, as well as the personal and sociopolitical dimensions in participant's stories. Furthermore, as researchers, in analysing and writing our findings, we acknowledge that we cannot stand apart from the narratives we produce, given that the texts we construct may emphasize more or less certain aspects of participants' experiences based on our understanding of the importance of participant narratives.

\section{Research Findings}

Six participants narrated their life stories in a moving and relatively direct way:

1) The story of Aeesha, a woman who actively pursued her career goals, both before and after the Syrian war, constantly overcoming obstacles that repeatedly came before her in order to create the professional circumstances she desired.

2) The story of Adira, a woman who changed from her traditional role as a woman responsible only for household matters, to the role of an assertive, extroverted person who courageously sought to secure the necessary conditions for her children both during the flight as well as during her stay in the host country. Her plans included going to school to get an education.

3) Ademar, a well-renowned artist, in Syria, and father of three children narrated his personal and family story with sensitivity and shared his hopes as well as his advice towards others.

4) The story of Azar, the wife of Ademar, who is especially proud of her family and all they were able to create before the beginning of the war in Syria. In fact she felt the need to show photographs of their beautiful house, and the life of the family before their flight, in order to confirm her identity as a person who was formerly a citizen before she acquired the label of refugee.

5) The story of Omar is intergenerationally traumatic as he and his family have experienced threats and losses. What gives him strength today is that he ensured his son's safety, and has hopes for securing a better life for him in another country.

6) The story of Orhan centers around his identity as a caretaker and protector of his children both before and after the war, and his goals to provide a better life for them in the future.

The analysis produced common patterns and variations in the context of the following thematic sequences: 1) Narratives from the past, 2) the dangerous journey from Syria to Greece across the Aegean sea, 3) stories related to the present and suggestions for improvement to the host country, 4) sources of support and resilience, 5) Participants' hopes and plans for the future.

\subsection{Narratives from the Past}

Participants narrated their lives before and after the war in Syria, the reasons they were forced to leave the country, the sociopolitical context in Syria, as well as the biographical rupture that occurred in their personal, family and work lives, once the war broke. 


\subsubsection{Life before the War in Syria: Stories of Freedom, Stories of Obstacles and Injustice}

Accounts of life before the war in Syria comprised a major area of discussion for all. There were both positive and negative experiences mentioned with reference especially to sociopolitical and economic circumstances. Some talked about a sense of "normality", satisfaction, safety, peace, freedom, with economic opportunities as it is the case for Orhan:

Things were quiet, ordinary. I built my business slowly, there was a demand for my work. My wife and I had four children, a very satisfying life, with ups and downs, but an overall sense of contentment. The only thing we wanted was to live a good quiet life until we grew old and then to go where all of us will go. We had a sense that life would go on like this. Our children would grow up, work and have families of their own. We had no sense that anything would change. My daughter got a baccalaureate, my son was studying to be an engineer in the university.

Similarly, Ademar, the artist, with a renown area of expertise, was even more positive in his account:

I lived a wonderful life, as did my family. I had my houses, my cars. I was very happy in this country where I lived. I felt like a king. Everything was good, and life was pure. Before the war there was safety and freedom in Syria.

Along these lines, Adira the married homemaker and mother of six related:

I come from a family with nine other siblings. I married at 14, I had my first child of six children at 16. Things were very good for us before the war began. We had a small farm at the edge of town. I was at home taking care of my children and my family. I worked with the goats I milked them... It was a peaceful life, ordinary, happy.

However others mentioned difficulties in daily life before the war. In particular, injustice brought about by practices of the regime, which is portrayed as " $a$ small group of people that controls everything and ignores the needs of the people".

Aeesha, a woman with strong career interests, who seems to define herself especially through her professional identity, she talked with pride about her great number of publications, and the constant obstacles she faced in her work environment that was controled by the politics of the government.

In my work there, I was the director, and I had raised the professional standards to a very high level. However, it was like they-the government, did not want me to succeed at something. I became very tired, trying to get somewhere with some kind of goal and then feeling like they turn it all back again.

There were also accounts of injustices, and losses because of government actions even of an intergenerational order, leading to the migration of citizens in order to survive or improve their daily living conditions. This is portrayed in Omar's account, as he talked about his life after the age of six when his father was killed by the government regime. In an intense emotional ambience, he recounted the story of "unfairness" that Syria and his family has suffered interge- 
nerationally because of the government since the beginning. He stressed the power of the government that controlled everything in the country. "It's a small family with so few people that keep the control".

My life was ruined, and I had no future after the army took my father when I was six. But even before that many people from Syria went abroad because they were in very bad straits, they needed to go abroad to find a better life...

In his narrative, paternal anxiety and desire for the future generations to not have the same experiences became also evident.

We have paid a high price in Syria and especially in this period of time... We do not want our children or our grandchildren to experience these injustices. The situation in Syria is very, very difficult and very unjust.

\subsubsection{A Growing Sense of Change}

In all narratives, reference was made to subtle indications of changes that became increasingly evident and disturbing. The presence of the army was increasingly apparent and oppressive.

In the words of Orhan:

These people started to appear, people with guns. They said they came to tell us about freedom, they said they wanted to liberate us. But they did not know what freedom meant. They said they were going to teach us history and religion. But they distorted our religion and they ruined it. I don't know what the aim of these people is. They wanted to take the country back and start from zero.

There was also a sense that the people with guns were strangers to the country.

I do not know who these people are really. I think [the regime] found anyone they could, a passing stranger and gave them a gun and that person could threaten anyone they wanted. These people are mainly uneducated, because anyone who is educated knows what freedom means. And these people, who came with guns, the only thing they wanted was to take money, create chaos, they're still doing that. These people are not Syrians. They have to do with foreign powers (Ademar).

The descriptions focused on the sense of gradual encroachment on the citizens, who in turn withdrew, trying to create distance between themselves and the armed men:

I am a man of peace, I did not want to go to one side or the other. I am not a soldier. I $m$ not a general I did not want to get involved and these things... I just wanted to go on with my life (Orhan)

I wanted to continue with my work. It is in very high demand, it was in demand from both sides, from people all over the world. I did not want to get involved in the conflict, in this situation. But I felt that I would be forced to soon (Ademar).

\subsubsection{Life after the Beginning of the War}

The participants related how their lives and the lives of their families drastically changed for the worse after the beginning of the war. The stories began with the 
description of the "bang" - the armed conflict increasingly evident in the towns. A common theme had to do with the lack of the basic services and goods, and the image of a country regressing to prior, much more difficult times. Running water, electricity food were scarce or even nonexistent.

First of all there was no water, no electricity we went back to old times, a hundred years before. We started to make wells like we did in the past, we tried to burn wood and other things to warm up (Ademar).

The sounds, images and bodily sensations from the vibrations of bombings and the fear of death predominated in the experience of all.

All day long you would hear bombs from airplanes, bullets, even at night you couldn't sleep because you didn't know if you would wake up to see the next day. And from the bombs everything shook-our bones even our stomachs. When I hear the sounds of the airplanes now $1 \mathrm{~m}$ afraid (Aeesha).

As participants started talking about the safety of their children, there were changes in bodily stance and movement-lowered gaze, uncomfortable smiles, intense hand movements and nonverbal expressions.

I was afraid for my children. I wanted to protect them. I knew in time one side or both sides were to take my children. They would train them and that would make them like them (Orhan).

My eldest son started to talk about joining the army, we didn't want him to do that so we moved into Aleppo. We tried to send our son abroad so he wouldn't go into the army. We sent him to Austria and he's still there. The other children stayed with us (Adira).

Omar talked about fears of his children being kidnapped to be taken into the army.

We kept hearing about these abductions of children. I would lock my child inside- he couldn't go out, it was like a punishment but even so I had to do that. Other parents did the same thing. Even though we also heard other stories. A father locked his child in and had to go take care of something for the house and the child got out and went up on the high flooring and jumped off. But I was afraid for my children I knew that the regime would come and take them.

A deep sadness for the children, for the significant rupture in the course of their development, their interrupted lives, and dreams was also heard in participant narratives.

My son was soon about to finish college. My children's future was just beginning, their dreams.... And that all stopped (Orhan).

\subsubsection{Positions Regarding the Cause of the War in Syria}

Although the participants came from different social strata, there was a consensus in all narratives, namely that the problems in Syria began and are due to the interference of foreign forces.

There were foreign hands involved-it's obvious. And when these foreigners came, these foreign powers, these foreign hands, they started interfering with the problems that the people of Syria had. These foreigners caused more problems 
and other groups began to emerge. And those are the people who ruined our Syria (Ademar).

There was also emphasis on the pretext of religion which gained ground especially among people without education:

These people came with the pretext they will come to teach us history, the history of our religion. But they distorted it, destroyed it (Orhan).

\subsubsection{The Flight}

1) Internal immigration in Syria in search of security.

The voyage of flight began with internal immigration in search of security, long before leaving Syria to go to another country. In total the participants lived five to six years in the war, traveling big distances under bombardment and the firing of snipers. They faced repeated traumatic and painful situations.

Families moved to other homes, basements, other cities to avoid contact with the armed men.

There was no safety. We were just in the middle on the one side to people with the guns on the other side the army. We had to leave my house we went to another city nearby we thought it was safe at the time we had to rent a house we began from zero we left with the shirts on our back. But then the same people came there with the guns again (Adira).

Originally we lived in the family compound. It was several houses joined together. My wife and I and our younger son lived in one. In the next house was my son his wife and two children. In a third house my daughter, son-in-law and her child. But as these people started coming around, saying they were going to liberate us, menacing people, I became afraid, I moved my family, everybody into a basement (Ademar).

At this point, the thought to immigrate, particularly to reunite with family members who live abroad was a recurring theme in many narratives.

2) Leaving the country: Passage to Turkey

The story of the voyage abroad had a particular place and significance. Descriptions were emotionally loaded when describing concerns about children leaving the country, passage through Turkey, and the stay in Turkey. Most interestingly and significantly, the descriptions of the voyage tended to be more detailed than accounts about other aspects of the experience, thus demonstrating the need to share these difficult and traumatic experiences that put their lives in danger. Again, for all participants children's safety and escape from Syria was a priority.

First the children went abroad, this is what everybody does, they send their children abroad. And for me the most important part of the story is that I managed to send my children abroad and then to follow them myself(Orhan).

The importance of the number of attempts to leave was also stressed. Somatic and psychological endurance was tested because of repeated failures.

I managed to finally leave on my eighth attempt. The first time they told us we had to cross a stream, and then a car will pass to take you around three in the 
morning. The second time we went over the mountain we wound up until the top but there we had to stop because they started shooting us from the side of Turkey at the border (Aeesha).

Moving through a country in war was life-threatening and terrifying.

The most difficult part of our trip was from Syria to Turkey. One day we had to sit without moving because there were many bombs so many snipers all around who shot. We were in a state of shock that day. What we lived through in one day, It was a shock that lasted a month (Adira)

It was chaos, terrorism everywhere (Azar).

The need to escape from the country was immense. Even a minimal movement away from Syria gave a sense of relief and freedom

I felt a sense of freedom-like the hands were being taken away from my throat (Aeesha).

A part of the trip involved a stay in Turkey, ranging from a few days, to many months. During this time the refugees needed to move within the country and to work in order to get money. In their narratives, a sense of frustration and despair were expressed concerning the circumstances, the lack of support and the legal framework that gave only very limited rights to refugees.

There was nothing of all of that they had told us. What we had heard that there would be organizations there to help us, guide us, people to listen to us, help us solve our problems. Nothing was true of all that we had heard. We were forced to rent a house, it was very expensive. You had to pay for all of your healthcare. We had money, so we could pay... but the money ran out. It got to the point where we even had to sell our cell phones in order to survive. They welcomed us to take our money-they did not care about us. We had to workthe children-my son who was 12 -in order to pay rent electricity and water to survive. We did not have the same rights as the Turkish people. We had no rights. As a refugee you had no rights-you couldn't raise your voice-as you can here in this country [Greece] (Orhan).

3) From Turkey to Greece-the Sea.

The trip from Turkey to Greece was the most onerous part of the journey. Participant descriptions were detailed and long and told with intense emotion. The experience was described to something "worse than hell". The boats used by the traffickers were overfilled at every point in the trip, while the cold created further problems. Participants repeatedly confronted situations of life and death, such as having to steer the boat themselves although they had no knowledge of how to do so. Yet that was the only way to get to a Greek island.

We were like sardines, about 72 people in a truck for many hours. When we got there and they blew up the rubber boat and put us inside... We were one on top of another, stacked up, it was very painful (Ademar).

It was something worse than hell, because we hear about hell but we don't live it. I put my life in danger three times. People were drowning, we were afraid for our lives. But unfortunately you had to do it to get to a better life (Orhan). 
In contrast to the terror of the ordeal of the trip, there were also unexpected instances of hope:

One other image that we had when we were in the boat-there were six dolphins directly in front of us, they were jumping up-and-down. We sat there and we looked at them and that was something that held us, it gave us hope, and it also prevented the boat from capsizing (Adira).

\subsection{Descriprions from the Present Time-The Host Country}

\subsubsection{Arrival and Internal Movement-Stories of Ambivalence in Greece}

The moment the participants found themselves in Greek soil, the rescue by the Greek authorities was described as giving them a sense of relief, safety. They felt welcomed. Here too, the emotions expressed were particularly intense. Gratitude was also frequently mentioned.

The Greek navy came and saved us. We felt safe, it was wonderful. We got to Chios. They welcomed us, received us, helped us (Ademar).

Since we managed to get safely to a country like Greece we thank God, and thank Greece (Orhan).

Refugee people initially viewed Greece as a temporary stop on their journey to another European country. However, this was not the case since the borders closed, in addition to a slow-moving bureaucratic process. In the meantime, participants had to move through various parts of the country before getting to the reception centers where they would be staying. Moving across the country, they experienced solidarity and humanity, which were perceived as a "reward" for the danger they put themselves, and were a source of support and hope for their future.

When we got to Greece we thought we would stay only for a week. This was not the case but we are glad we stayed and we met people. Not only these in the receiving organization (NGO). Just common people in general. I saw Greek families with cars, scooters, older people, children wanting to help. It was something unbelievable what we experienced in Greece (Ademar).

Participants had conflicting feelings, however, when they began to experience difficulties in reception centers, where appropriate living conditions were not always available. In all, they experienced their stay in Greece as both safe and unsafe. On the one hand they had been saved from the dangers of the war and their trip, on the other their documentation processes were delayed, Greece was in an economic crisis confronting difficulties that were evident in the reception centers and in the neighborhoods they lived in.

We had problems because there were many mice. The toilets were not clean and there were no showers. We had to go to another place to bathe. When we went to speak to the authorities - that was the problem. Many things were lacking - things were not well organized. I asked them, "Why do I have to go through all this-P ve been through so much, could I at least be put in a nicer place?" (Aeesha). 


\subsubsection{Needs and Suggestions for Improvement in Conditions in the Host Country}

Refuggee people made suggestions regarding improvement in living conditions, bureaucratic processes providing documentation and other services, as well as the provision of information regarding countries that refugees could move. They also proposed a more personalized approach towards the needs of each individual and utilization of people's specific skills and capabilities-particularly those of women. Aeesha, the professional woman, emphasized especially the importance of involving women in an active way, either by making good use of the knowledge they already have or by helping them acquire new skills.

They should look at the problem each person has, individually, in detail. The person's needs, health, skills. The language that they know, their craft. Particularly the women. They should not let them just sit, drink, eat, sleep. They should do something, learn things... In the island of Leros, I taught women how to sew and they were eager to learn.

Finally, securing children's education and socialization with other children, was of major significance for our participants. Attending school, even temporarily, was perceived as promoting childrens' psychosocial well-being and this gave joy to the parents as well.

Here things are good. My son goes to school, he has friends. Just seeing him laugh with other children, it's enough for me (Omar).

\subsection{Narratives about the Future Plans, Expectations Hopes for the Future Place of Residence}

The participants talked about their expectations, feelings, thoughts and plans for the time period to come after they leave Greece to another European country. Greece was for them a temporary refuge, while reunion with family in other countries was their main expectation involving both anxety and hope. Securing a decent quality of life for their children in the future was a goal that provided a source of strength for the participants. As Orhan emphasized:

Above all are the children. Everything I did I did for them to secure their future as I did in Syria before the war began. I will continue to do it until I reach my goal. The future is those children. It's for them that I try and that I am in this continuous struggle, this is what I get strength from to continue this struggle.

I myself have no dreams... the only thing I want to see is my son realizing these dreams. Because for me it is really a waste of time (...) what I want is to see this in my son, and to try and give the best that I can and to take him to a safer place (Omar).

Finally, it should be noted that education seems to be a goal not only for the children but also for certain participants, indicating personal change and growth as a result of new experiences in their lives.

I want to go to school because I want to learn and to explore things I have not as yet (Adira) 


\subsection{Coexistence of Multiple Narratives Stories of Resistance, Resilience, Adaptation and Personal Growth}

Participants referred both to external cirmunstances which forced them to make the decision to leave and to continue their journey despite the overwhelming difficulties, but also emphasized personal beliefs, values, qualities and abilities which served as protective factors and sources of motivation, support and resilience in their lives. Recurrent themes in their stories included belief in human strength, stubborness, cooperation, flexibility, openess, respect for oneself and others, hope for change, belief in God, belief in human goodness, even personal growth, and most of all caring for the children and the prospect of being reunited with family.

Orhan talked about inherent human strength emerging in extreme and dramatic circumstances:

If the person has will and strength inside when he gets to such a dramatic situation he is forced to find all the strength. If you know that if you stay here you will die otherwise you have to find a way-then you find the strength. Everyone can find it. What would someone prefer-to die or to send their children away and then follow them. We all have the strength inside of us but until we reach our limit we don't know we have it (Orhan).

For Orhan, stuborness proved also a valuable "skill".

What gave me strength was that I had this particular skill. To keep going. The more things were against me and the more this gave me strength. From the stubbornness that I had, the belief that I was going to achieve something.

For Aeesha, knowledge and faith in her own abilities, perserverance, and eagerness to reunite with her daughter.

For Omar, prayer and faith in God

These are all things from God because we are God's people. As God gives us things as we pray towards him that gives us patience and strength.

For Ademar, respect for oneself and others, flexibility and openness, making plans for the future proved especially important for adaptation at the host country.

Notably, Adira underscored how the experience of immigration contributed to a radical change and personal tranformation, and the importance of keeping refugee people active and mobilized in relation to their needs and goals.

Before the war I only stayed and worked in my house. My husband went shopping even for my own clothes and personal objects. Now I am no longer afraid and I feel confident to go out in the world and to take care of my daughter who has a mental health problem. The people, here [NGO] mobilized me towards this goal as they encouraged me to do things on my own. For example, getting a paper, taking my daughter to the hospital, etc. I also make plans for the future and this keeps me strong for the present time.

\subsection{Life Experiences: Messages to Give Support and Strength to Other People}

Finally, the participants expressed beliefs, attitudes and values with respect to 
human life hoping to inspire help and strengthen others, both refugees and non-refugees. More specifically through messages of solidarity and world peace they encourage others to enjoy the one life they have, and the small daily joys it offers.

The message I want to give is that in this life and on this earth we are born and live once. I hope that we have peace so that each person can have a good life whatever religion he or she practices. The only thing you should do is enjoy life until you go to the grave because we will all go there sometime-to enjoy simple small details of life from the hour you will born until the hour you die (Orhan).

Life is compared to a smile and the values of patience and will, as well as the presence of important people are sources of inspiration and strength.

Life is a smile. In life you have to have patience and you have to try and that anything can be done. Fortunately I have people near me and I have the will to do things (Ademar).

Finally, participants encourage their children to be stronger than they are, to be assertive, to make decisions in order to have a better life.

I want them to be stronger than I am to have a better life than I did (Adira).

\section{Conclusion and Discussion}

Narrative interviews facilitated participant Syrian refugees to have their voices heard in a relatively direct way, and to bring out the richness, the complexity and the particularity of their experiences. Participants as main narrators and self-aware embodied agents recounted stories taking into account time and place as well as specific socio historical circumstances. They reflected upon their lives, identity, parental roles, goals, and choices made, in the past, before and after the beginning of the war in Syria, during their escape and dangerous journey, and upon their arrival in Greece with destination another European country. Aware of the extreme adversities and obstacles they had already overcome, the biographical rupture and changes in their personal, familial and work lives, they also talked about their values, attitudes, strengths, capacities, personal growth, hopes and plans for the future both for themselves and their families. Moreover, they reflected upon their experiences and shared pieces of advice aiming to support and encourage other people. Others stressed the universality of human nature and the finality of human existence, reminding us that all people are for the main part alike, and it is only life circumstances that force them to enter the classificatory space of "refugee" (Shneikat \& Ryan, 2017). This was further underlined by Azar who shared photographs with us depicting her family and house from the time of "normality" before the Syrian war and the biographical rupture in her life (Camia \& Zafar, 2021).

For all participants, the main reasons for leaving the country had to do with the violent circumstances of the war, their search for safety and the fact that life in Syria was no longer viable (Shneikat \& Ryan, 2017; UNHCR, 2015). However, for some there were added reasons which existed even before the war, such as 
intergenerational persecution and losses brought about by the government, as in the case of Omar, or governmental control which interfered with their professional development. For example, for Aeesha, the fact that she was able to escape not only from the tragedy of the war but also from the suffocating atmosphere created by the government was particularly liberating as she now felt free to dream with her family and to think about professional goals. On the other hand Ademar described a most satisfying life before the war, and the wish to return to his country when things improve. Only two (Ademar and his wife) of the six participants expressed the wish to repatriate at some point, which stands in contrast to the view that the experience of flight from the home country is always accompanied by the desire for repatriation (Den Boer, 2015). Finally, for Adira, leaving the country proved to be an experience of personal growth and transformation, as she became more autonomous and confident about herself and hers abilities (Hunt, 2008).

A pervasive theme in people's stories was the repeated attempt to escape from Syria to Turkey and from Turkey to Greece. They constantly felt that this process was endless as they no sooner arrived at a destination than they had to regroup after all the hardships and adversities in order to secure the continuation of their journey. Their life was transformed into a life of constant movement from one checkpoint to another without the possibility of long term planning and with the constant possibility of the journey coming to an end (Jovanović, 2017). Greece was another such point where they were forced to remain in limbo, in "liminal spaces of temporary dwellings" for a significant period of time (Arvanitis, Yelland, \& Kiprianos, 2019; Den Boer, 2015). Moreover, they had to also cope with the difficulties created by the protracted economic crisis of the host country and its negative consequences for refugee psychosocial care (Kalantzakos, 2017).

Participants had mixed experiences and feelings. On the one hand, they felt and expressed significant gratitude for the refuge and support they received from the Greek state and people's care, solidarity and sympathy. On the other they found themselves in circumstances that were difficult to cope with. Besides their request for improvement in the living conditions in the reception centers, they proposed an individualized and respectful approach to the needs of refugee people which aims at more rapid solutions for issues such as bureaucratic procedures and the securing of legal residence and transit documentation (Crawley et al., 2016). Other suggestions included information dissemination regarding the countries of relocation as well as the creation of programs for the use of human potential and the utilization of refugees' specific skills and abilities through which they may regain a sense of autonomy and normality (Betts \& Collier, 2017). The role of the school was deemed essential both for the children's psychosocial development and social integration, as well as for parents' wellbeing and empowerment, who can thus feel that they provide their children with safety and a sense of normality as they are again involved in roles of daily life (Crul, Lelie, Biner et al., 2019; UNHCR, 2018b). Little attention has been given so far to the study of 
experiences and needs of refugees in intermediate or first asylum countries, with research focusing mainly in refugee settlement countries (Mohamed \& Bustag, 2021; Shneikat \& Ryan, 2017).

Finally, the Syrian participants talked about the values, the supportive factors and the sources of strength which accompanied them throughout their journey and new life. The value of the family and of parenthood-as well as sacrifices and self-denial in order to provide a better life for them-seemed to comprise powerful motives, and sources of empowerment and resilience in all of the situations throughout their journey for a better future (Crawley et al., 2016; Shneikat \& Ryan, 2017; Merry et al., 2017). In addition, faith in God, patience, will, perserverance, flexibility, adaptability, respect for oneself and for others, creativity, hope for change, belief in human capability and "good luck" were also noted as sources of strength and support (Al-Smadi et al., 2017 in Alzoubi et al., 2017).

Overall, participants' narratives in our study seem to deconstruct the common portrayal of refugees as a-historical subjects, helpless, passive dependants with limited ability for agency (Ghorashi, 2005; Malkki, 1996; Mcmahon et al., 2016), as well as the "deficit model" which emphasizes vulnerability and trauma (Bogic et al., 2015; Papadopoulos, 2002) at the expense of positive adaptation, coping strengths and resilience in refugee lives (Mohamed \& Bastug, 2021; Hutchinson \& Dorsett; Shneikat \& Ryan, 2017). Biographical interviews facilitated Syrian refugees who found temporary refuge in Greece to articulate their life stories, socio historical circumstances and specific needs, as active responsible, competent, selfdetermined agents. Adopting a social justice and strengths based outlook (Goodman et al., 2004; Johnson \& Parry, 2015), we hope that refugee voices can influence societal discourses, interventions and policy development. In addition, we propose that refugee services (e.g. health and counseling services) help amplify refugees' voices; build on their strengths, capabilities and growth potential; mobilize and encourage new learning; advocate for the refugee situation; develop programs and design community interventions taking into account refugees' own suggestions, requests, and needs assessment. Lastly, we recognize the diversity and multiplicity in the study of refugee people and acknowledge that different conceptualizations, methodological approaches and more complex ways of addressing our data are possible.

\section{Acknowledgements}

We would like to extend our heartfelt thanks to the participants in our study, the interpreters, the collaborating team of the human rights organization (NGO), especially N. Kanakis, A. Yfantis, I. Kalyvopoulos and our colleagues N. Tzavaras and $\mathrm{D}$. Ploumbides for their valuable contribution to the research endeavor.

\section{Conflicts of Interest}

The authors declare no conflicts of interest regarding the publication of this paper. 


\section{References}

Aboud, S. N. (2018) Syria (2nd ed.). Polity.

Al-Zoubi, F. A., Al-Smadi, A., \& Gougazeh, Y. M. (2017). Coping Strategies Used by Syrian Refugees in Jordan. Clinical Nursing Research, 1-26.

Anagnostopoulos, D. C., Giannakopoulos, G., \& Christodoulou, N. G. (2017). The Synergy of the Refugee Crisis and the Financial Crisis in Greece: Impact on Mental Health. International Journal of Social Psychiatry, 63, 352-358. https://doi.org/10.1177/0020764017700444

Arvanitis, E., Yelland, N. J., \& Kiprianos, P. (2019). Liminal Spaces of Temporary Dwellings: Transitioning to New Lives in Times of Crisis. Journal of Research in Childhood Education, 33, 134-144. https://doi.org/10.1080/02568543.2018.1531451

Bergen, N. (2018). Narrative Depictions of Working with Language Interpreters in CrossLanguage Qualitative Research. International Journal of Qualitative Methods, 17, 1-11. https://doi.org/10.1177/1609406918812301

Berman, C. R., \& Tyyskä, V. (2011). A Critical Reflection on the Use of Translators/Interpreters in a Qualitative Cross-Language Research Project. International Journal of Qualitative Methods, 10, 178-190. https://doi.org/10.1177/160940691101000206

Betts, A., \& Collier, P. (2017). Refuge: Rethinking Refugee Policy in a Changing World. Oxford University Press.

Bogic, M., Njoku, A., \& Priebe, S. (2015). Long-Term Mental Health of War-Refugees: A Systematic Literature Review. BMC International Health and Human Rights, 15, Article No. 29. https://doi.org/10.1186/s12914-015-0064-9

Bruner, J. S. (2002). Making Stories: Law, Literature, Life. Harvard University Press.

Camia, C., \& Zafar, R. (2021). Autobiographical Meaning Making Protects the Sense of Self-Continuity Past Forced Migration. Frontiers in Psychology, 12, Article ID: 618343. https://doi.org/10.3389/fpsyg.2021.618343

Crawley, H., Duvell, F., Jones, K., \& Skleparis, D. (2016). Understanding the Dynamics of Migration to Greece and the EU: Drivers, Decisions and Destinations. MEDMIG Research Brief, 2.

Crul, M., Lelie, F., Biner, Ö. et al. (2019). How the Different Policies and School Systems Affect the Inclusion of Syrian Refugee Children in Sweden, Germany, Greece, Lebanon and Turkey. Comparative Migration Studies, 7, Article No. 10.

https://doi.org/10.1186/s40878-018-0110-6

Den Boer, P. (2015). Liminal Space in Protracted Exile: The Meaning of Place in Congolese Refugees' Narratives of Home and Belonging in Kampala. Journal of Refugee Studies, 28, 486-504. https://doi.org/10.1093/jrs/feu047

Ellingson, L. (2017). Embodiment in Qualitative Research. Taylor \& Francis. https://doi.org/10.4324/9781315105277

Freedman, J. (2018). The Uses and Abuses of "Vulnerability" in EU Asylum and Refugee Protection: Protecting Women or Reducing Autonomy? Papeles del CEIC, 2019, 1-15. https://doi.org/10.1387/pceic.19525

Garoff, F. et al. (2021). Mental Health and Traumatization of Newly Arrived Asylum Seeker Adults in Finland: A Population-Based Study. International Journal of Environmental Research and Public Health, 18, 7160. https://doi.org/10.3390/ijerph18137160

Gergen, K. (2015). From Mirroring to World-Making: Research as Future Forming. Journal for the Theory of Social Behaviour, 45, 287-310. https://doi.org/10.1111/jtsb.12075

Ghorashi, H. (2005). Agents of Change or Passive Victims: The Impact of Welfare States 
(the Case of the Netherlands) on Refugees. Journal of Refugee Studies, 18, 181-198. https://doi.org/10.1093/refuge/fei020

Goodman, A. L., Liang, B., Helmw, E. J., Latta, E. R., Sparks, E., \& Weintraub, R. S. (2004). Training Counseling Psychologists as Social Justice Agents: Feminist and Multicultural Principles in Action. The Counselling Psychologist, 32, 793-837.

https://doi.org/10.1177/0011000004268802

Hassan, G., Ventevogel, P., Jefee-Bahloul, H., Barkil-Oteo, A., \& Kirmayer, L. J. (2016). Mental Health and Psychosocial Wellbeing of Syrians Affected by Armed Conflict. EPidemiology and Psychiatric Sciences, 25, 129-141. https://doi.org/10.1017/S2045796016000044

Hunt, L. (2008). Women Asylum Seekers and Refugees: Opportunities, Constraints and the Role of Agency. Social Policy and Society, 7, 281-292. https://doi.org/10.1017/S1474746408004260

Hutchinson, M., \& Dorsett, P. (2012). What Does the Literature Say about Resilience in Refugee People? Implications for Practice. Journal of Social Inclusion, 3, 55-78. https://doi.org/10.36251/josi.55

Issari, P., \& Karayianni, Th. (2013). Greek Mothers' Narratives of the Construct of Parental Involvement. European Journal of Counseling Psychology, 2, 17-32. https://doi.org/10.5964/ejcop.v2i1.3

Issari, P., \& Pourkos, M. (2015). Qualitative Research Methods in Psychology and Education. Hellenic Academic Libraries. http://hdl.handle.net/11419/5826

Johnson, C., \& Parry, D. (Eds.) (2015). Fostering Social Justice through Qualitative Inquiry: A Methodological Guide. Taylor \& Francis. https://doi.org/10.4324/9781315428253

Jovanović, M. S. (2017). “I Refuse to Sink”: Narratives of the Dispossessed within Refugee Stories on the Balkan Route. Cultural Studies-Critical Methodologies, 18, 251-258. https://doi.org/10.1177/1532708617737097

Kalantzakos, S. (2017). A Paradox in Today's Europe: Greece's Response to the Syrian Refugee Crisis. Jean Monnet Centre of Excellence of the University of the Peloponnese. The Jean Monnet Papers on Political Economy, No. 15.

Kesisoglou, G., \& Issari, P. (2019). Supervision Arrangements: Methodological Experiences and (In)decisions on Researching Affective Entanglements. Entanglements, 2, 41-58.

Malkki, L. H. (1996). Speechless Emissaries: Refugees, Humanitarianism, and Dehistoricization. Cultural Anthropology, 11, 377-404. https://doi.org/10.1525/can.1996.11.3.02a00050

Masten, A. S. (2014). Global Perspectives on Resilience in Children and Youth. Child Development, 85, 6-20. https://doi.org/10.1111/cdev.12205

Mayblin, L. (2014). Asylum, Welfare and Work: Reflections on Research in Asylum and Refugee Studies. International Journal of Sociology and Social Policy, 34, 375-391. https://doi.org/10.1108/IJSSP-11-2013-0113

Mcleod, J. (1997). Narrative and Psychotherapy. SAGE. https://doi.org/10.4135/9781849209489

Mcmahon, S., Crawl, H., \& Jones, K. (2016). Victims and Villains. Migrant Voices in the British Media. Coventry University.

Merry, L., Pelaez, S., \& Edwards, N. C. (2017). Refugees, Asylum-Seekers and Undocumented Migrants and the Experience of Parenthood: A Synthesis of the Qualitative Literature. Global Health, 13, 75. 
Mishler, E. G. (1986). Research Interviewing. Context and Narrative. Harvard University Press.

Mohamed, E., \& Bastug, M. (2021). Syrian Refugees in Canada and Transculturalism: Relationship between Media, Integration and Identity. Journal of Refugee Studies, 34, 219-240. https://doi.org/10.1093/jrs/feaa009

Operational Data Portal (2021). Mediterranean Situation-Greece. https://data2.unhcr.org/en/situations/mediterranean/location/5179

Papadopoulos, R. (Ed.) (2002). Therapeutic Care for Refugees. No Place Like Home. Karnac.

Patton, M. Q. (2002). Qualitative Research and Evaluation Methods. Sage Publications.

Polkinghorne, D. E. (1988). Narrative Knowing and the Human Sciences. State of New York University Press.

Riessman, K. C. (2008). Narrative Methods for the Human Sciences. Sage Publications.

Shneikat, B., \& Ryan, C. (2017). Syrian Refugees and Their Re-Entry to Normality the Role of Service Industries. The Service Industries Journal, 38, 201-227. https://doi.org/10.1080/02642069.2017.1387539

Smith, B., \& Sparkes, A. C. (2006). Narrative Inquiry in Psychology: Exploring the Tensions within. Qualitative Research in Psychology, 3, 169-192. https://psycnet.apa.org/doi/10.1191/1478088706qrp0680a https://doi.org/10.1191/1478088706qrp068oa

Temple, B., \& Young, A. (2004). Qualitative Research and Translation Dilemmas. Qualitative Research, 4, 161-178. https://doi.org/10.1177/1468794104044430

Tribe, R., \& Thompson, K. (2011). Developing Guidelines on Working with Interpreters in Mental Health: Opening up an International Dialogue? International Journal of Culture and Mental Health, 4, 81-90. https://doi.org/10.1080/17542863.2010.503365

Tsiolis, G. (2006). Lifestories and Biographical Narratives: The Biographical Approach in Sociological Qualitative Research. Kritiki Publications.

UNHCR (2015). Over One Million Sea Arrivals Reaching Europe in 2015. United Nations High Commissioner for Refugees.

https://www.unhcr.org/news/latest/2015/12/5683d0b56/million-sea-arrivals-reach-euro pe-2015.html

UNHCR (2018a). Situation on Greek Islands Still Grim Despite Speeded Transfers. United Nations High Commissioner for Refugees. http://www.refworld.org/docid/5a3cec6b4.html

UNHCR (2018b). Turn the Tide: Refugee Education in Crisis. United Nations High Commissioner for Refugees. https://www.unhcr.org/turnthetide/ 